\title{
Using lon Exchange Process in Removal of Selected Organic Pollution from Aqueous Solutions
}

\author{
Jadwiga Kaleta', Dorota Papciak', Alicja Puszkarewicz \\ 1 Rzeszów University of Technology, The Faculty of Civil and Environment Engineering and Architecture, \\ Department of Water Purification and Protection, ul. Poznańska 2, 35-084 Rzeszów, Poland \\ * Corresponding author's e-mail: jkaleta@prz.edu.pl
}

\begin{abstract}
Surfactant and phenol were removed using AMBERLITE IRA $900 \mathrm{Cl}$ ion-exchange resin, which is a strong alkali. In the process, the tests were carried out under non-flow conditions, the effect of contact time and ionite dose on the surfactant and phenol exchange was determined. The tests under the through-flow conditions were realized in three consecutive cycles, preceded by regeneration and rinsing. The obtained results served for determination of ionexchange capabilities of the studied ionite. The usable ion-exchange capabilities of the resin obtained after the second and third ionite operation cycle were lower by about 10\% (surfactant) and 14.29-17.86\% (phenol) than those after the first cycle. It shows that the process of sorption occurred simultaneously with the ion-exchange process.
\end{abstract}

Keywords: detergent, phenol, ion-exchange

\section{INTRODUCTION}

Detergents, as well as phenol and its compounds belong to the group of organic compounds which are dangerous to human health. Detergents constitute a commonly used name for surfaceactive agents (SAAs), which mix with the surface water and groundwater through the municipal and/or industrial wastewater. The compounds hinder the self-purification processes of waters and accumulate in living organisms [Sarkar and Das 2001, Kida and Koszelnik 2015].

SAAs belong to the group of very durable and slowly biodegradable compounds. In the water intended for human consumption, they are present as a result of insufficient water purification. The compounds facilitate absorption of other toxic substances (such as pesticides and polycyclic aromatic hydrocarbons) from the digestive tract to the blood through the decrease of surface tension. They have a harmful effect on skin, causing its dryness, cracking, irritation, and various kinds of eczema. They destroy mucosa of the digestive tract, which causes gastritis [Kaleta 2008].
An effective method of detergents removal is adsorption. In the process of granular activated carbon adsorption, $31.7-67.4 \%$ of anionic and non-ion SAAs were removed [Cserhati et al. 2002]. The adsorption capacity of granular activated carbon produced in Poland towards anionic SAAs was between 11 and $17 \mathrm{mg} / \mathrm{g}$ [Kaleta 2008]. Meanwhile, the activated carbon dust removed $34-38 \%$ of anionic SAAs, and $68-98 \%$ of cationic SAAs [Basar et al. 2004]. Other sorbents used for SAAs sorption were: activated oxygen and mineral clays.

The ultrafiltration process was found to be very effective in anionic surfactant removal in a wide range of concentrations, the retention coefficient amounted to $82-90 \%$ [Kowalska 2008].

The anionic surface-active agents were effective in the ion exchange process of gel and macroporous anion-exchange resins [Kowalska 2009].

The source of phenol in the natural waters can be products of degradation of organic substances, as well as industrial wastewater, i.a. from coking plants and chemical industry. Phenols are toxic substances, which negatively influence the water 
environment. At concentration over $5 \mathrm{mg} / \mathrm{dm}^{3}$, they are toxic to the aquatic fauna and flora; they also hinder the water self-purification processes [Piekutin 2011, Puszkarewicz et al. 2015].

Phenol is a strong toxin. It has transfixing effect on the nervous and cardiovascular systems. It damages the respiratory tract, causes denaturation of proteins, and results in skin irritation. The water chlorination process creates chlorophenols, toxic compounds that cause the water intended for consumption to have unpleasant smell and changed taste [Kaleta 2006].

The most effective method of water purification of phenols and their products is the adsorption of activated carbons [Oghenejoboh et al. 2016]. The adsorption capacity of activated carbons produced by Gryfskand Sp. z o.o. company in Hajnówka, Poland, is between 35 and $50 \mathrm{mg} / \mathrm{g}$ [Kapica et al. 2002, Kaleta 2006]. The spherical activated carbons, received in the process of agglomeration of granular hard coking coal with vegetables oils (rapeseed and flaxseed) are characterised with a higher adsorption value (between 70 and $150 \mathrm{mg} / \mathrm{g}$ ) [Lorenc-Grabowska and Gryglewicz 2002].

An attempt has been made to replace activated carbons with other adsorbents, such as: granular coke, bituminous coal, peat, calcium carbonate, bog iron ore, natural and modified zeolites, bentonites, and modified clays. These adsorbents, despite their lesser adsorption capacity, may replace activated carbons under certain conditions [Nayak and Singh 2007, Kaleta et al. 20013, Dudzik and Werle 2015].

Phenolic compounds were effectively removed by Amberlite XAD resin. Its sorption capacity was higher for chlorophenol $(2.27 \mathrm{mmol} / \mathrm{g})$ than for phenol $(1.50 \mathrm{mmol} / \mathrm{g})$. Resin regeneration was conducted through extraction (elution) with methanol as a solvent. After subsequent desorption processes, the adsorption capacity did not change [Abburi 2003/B].

An effective method of removal of organic pollution from water is MIEX process (Magnetic Ion Exchange Process), in which selective ion-exchange resins of strongly alkaline function groups, working in a chloride cycle were used. The resins, produced in the form of "magnetic" microions, under appropriate hydraulic conditions underwent agglomeration and separation from the purified water. The MIEX method was utilised along with the coagulation process in order to maximize the effect of water purification process [Mołczan and Biłyk 2006, Kabsch-Korbutowicz 2013].

\section{RESEARCH SUBJECT}

The research focused on the removal of an anionic surface-active agent and phenol. The pollution is being limited in water for human consumption (Table 1).

According to the World Health Organisation (WHO) recommendations, the maximum concentration of anionic surface-active agents in the water intended for consumption is $0.2 \mathrm{mg} / \mathrm{dm}^{3}$. In the water intended for human consumption, WHO also limits by-products of chlorination, among them 2,4,6 - trichlorophenol, the maximum concentration of which is $0.01 \mathrm{mg} / \mathrm{dm}^{3}$ [Guidelines 2017].

The research was conducted on model solutions, called also initial solutions, which were prepared on the basis of distilled water. The means of control determination were indicators of the pollution types under research.

Model solution of the detergent (D) was prepared by adding distilled water to the Aerosol OT-100 anionic surface-active agent (chemical formula $\mathrm{C}_{2} \mathrm{H}_{37} \mathrm{NaO}_{7} \mathrm{~S}$ ) in an amount that results in detergent concentration in the solution equal to $20.00 \mathrm{~g} / \mathrm{m}^{3}$. Determination of the detergent was carried out using the method involving methylene blue. The method consisted in creating blue organic compound as a result of reaction of methylene blue with anion-exchange surface-active agent. The created compound was extracted with chloroform in alkaline environment, and the intensity of the blue hue, measured photometrically at the wavelength equal $\lambda=652 \mathrm{~nm}$, was proportional to the concentration of detergents.

The phenolic pollution was investigated on the example of the most often occurring compound, which is phenol $\left(\mathrm{C}_{6} \mathrm{H}_{5} \mathrm{OH}\right)$. Phenol was dissolved in distilled water, transforming into model solution (F) with the concentration of $20.00 \mathrm{~g} / \mathrm{m}^{3}$. Determination of the phenol concentration was carried out using an indirect method through the absorption measurement (with the wavelength of $\lambda=254 \mathrm{~nm}$ ) by means of a Schimadzu UV-1601

Table 1. The admissible concentration of surfactant and phenol in natural waters, $\mathrm{mg} / \mathrm{dm}^{3}$ (Council Regulation No. 203, item 1718 of 27 November 2002)

\begin{tabular}{|l|c|c|c|}
\hline Type of pollution & $\begin{array}{c}\text { Category } \\
\text { A1 }\end{array}$ & $\begin{array}{c}\text { Category } \\
\text { A2 }\end{array}$ & $\begin{array}{c}\text { Category } \\
\text { A3 }\end{array}$ \\
\hline Surfactant & 0,2 & 0,2 & 0,5 \\
\hline $\begin{array}{l}\text { Phenols } \\
\text { (phenolic index) }\end{array}$ & 0,001 & 0,005 & 0,1 \\
\hline
\end{tabular}


Visible Spectrophotometer. Quartz cuvettes with $1 \mathrm{~cm}$ absorption layer were used. Before carrying out the actual measurements, a model curve was created, and the correlation between phenol content $\mathrm{F}$ and absorbency $\mathrm{A}$ was determined by the following formula (1):

$$
\begin{aligned}
& \mathrm{F}=\operatorname{tg} 35 \cdot \mathrm{A} \operatorname{tg} 35=0.700, \\
& \text { that is } \mathrm{F}=0.700 \cdot \mathrm{A}
\end{aligned}
$$

A strongly alkaline AMBERLITE IRA900 $\mathrm{Cl}$ resin was used in the ion exchange process (Table 2). It is a macroporous type I resin, consisting of quaternary amine groups. It allows to remove all anions from the water, including the poorly decomposed ones, e.g. silica. The macroporous structure of the resin resembles a sponge. That feature, combined with a strong alkalinity, allows to remove large organic particles.

\section{RESEARCH METHODOLOGY}

\section{Tests conducted under non-flow (static) conditions}

Before the tests were conducted, the ion exchanger had been soaked in distilled water for 24 hours. An appropriate amount of the swelled ion exchanger was placed in a bottle of $10 \% \mathrm{NaCl}$. The bottle contents were shaken for $30 \mathrm{~min}$; then the ion exchanger was drained and rinsed with distilled water until the disappearance of Cl- ions.

The regenerated and rinsed resin was used for further tests. The kinesis of the ion exchange process was determined using the following method: $3 \mathrm{~g}$ of the ion exchanger were added to 8 bottles, each of them containing $1 \mathrm{dm}^{3}$ of an appropriate model solution. The samples were shaken for 10-180 min, and then underwent 30 minutes of decantation. Afterwards, the solution above the

Table 2. Characteristics of AMBERLITE IRA900 Cl

\begin{tabular}{|l|c|c|}
\hline \multicolumn{1}{|c|}{ Designation } & Unit & Value \\
\hline Bulk density & $\mathrm{g} / \mathrm{dm}^{3}$ & $640-710$ \\
\hline Granulation & $\mathrm{m}$ & $>500$ \\
\hline Effective diameter & $\mathrm{m}$ & $600-800$ \\
\hline $\begin{array}{l}\text { Coefficient of } \\
\text { homogeneity }\end{array}$ & - & $<1,8$ \\
\hline Humidity & $\mathrm{val} / \mathrm{dm}^{3}$ & 1,0 \\
\hline $\begin{array}{l}\text { Total ion } \\
\text { exchange } \\
\text { capacity }\end{array}$ & & \\
\hline
\end{tabular}

ion exchanger was removed, infiltrated, and the control determination was carried out.

In order to determine the influence of the ion exchanger dose on the ion exchange process, $1 \mathrm{dm}^{3}$ of a model solution and ion exchanger doses increasing from 0.5 to $7.0 \mathrm{~g} / \mathrm{dm}^{3}$ were added to 8 bottles. The contact time was $30 \mathrm{~min}$. After 30 min of sedimentation, control determination of decanted and infiltrated solutions was carried out. The results obtained in this series of tests were used to calculate the exchange capacity of the ion exchanger.

The exchange capacity of the ion exchanger in a moist state $(\mathrm{Zcw})$ was calculated by the following formula (2):

$$
Z C W=\frac{(C o-C k) \cdot V}{G}
$$

where: $\mathrm{Co}$-initial concentration of the model solution, $\mathrm{mg} / \mathrm{dm}^{3}$,

$\mathrm{Ck}$ - final concentration of the model solution, $\mathrm{mg} / \mathrm{dm}^{3}$,

$V$ - volume of the of the model solution used in tests, $\mathrm{dm}^{3}$,

$G$ - mass of the moist ion exchanger, g,

$Z c w$ - the exchange capacity of the moist ion exchanger, $\mathrm{mg} / \mathrm{g}$.

In order to calculate the exchange capacity of the dry ion exchanger, the moisture of the ion exchanger sample used in the research was determined (p). The exchange capacity of the ion exchanger in a dry state (Zcs) was calculated by the following formula (3):

$$
Z c s=\frac{100 \cdot Z c w}{100-p}
$$

where: Zcs - exchange capacity of the ion exchanger in a dry state, $\mathrm{mg} / \mathrm{g}$,

$p$-percent of moisture content in the ion exchanger sample.

\section{Determining exchange capacity of the ion exchanger under flow (dynamic) conditions}

The useful (working) exchange capacity was determined using laboratory ion exchanger columns made of organic glass with the diameter of $15 \mathrm{~mm}$ and height of $600 \mathrm{~mm}$.

In order to conduct the tests, a $20 \mathrm{~g}$ sample of the swelled (soaked) ion exchanger was transferred to the ion exchanger column. Then, about $1.5 \mathrm{dm}^{3}$ of the regenerant solution $(10 \% \mathrm{NaCl})$ was flushed through the ion exchanger at the 
speed of $5 \mathrm{~m} / \mathrm{h}$, downwards. Afterwards, the ion exchange bed was rinsed with distilled water until the disappearance of the regenerant solution in the outflow.

The actual tests consisted of flushing the appropriate model solution through the ion exchanger at the speed of $10 \mathrm{~m} / \mathrm{h}$. After each flow of $1 \mathrm{dm}^{3}$ of the model solution through the ion exchanger had finished, the samples were collected and control determination was carried out. The ion exchange cycle was stopped when the concentration of the detergent in the outflow increased above $0.6 \mathrm{mg} / \mathrm{dm}^{3}$, and of phenol above $0.2 \mathrm{mg} / \mathrm{dm}^{3}$ (cycle I).

Then, the ion exchanger underwent the regeneration and rinsing again; then it was used for another filtration cycle (cycle II) in the way described above. The whole sequence was repeated one more time (cycle III).

The useful (working) exchange capacity of the moist ion exchanger was calculated with the following formula (4):

$$
Z u w=\frac{V r \cdot \Delta C}{G j}
$$

where: $\Delta C$ - difference between the concentrations of the removed ions (initial concentration minus concentration puncture point), $\mathrm{mg} / \mathrm{dm}^{3}$,

$\mathrm{Vr}$ - volume of outflow from the column until puncture point, $\mathrm{dm}^{3}$,

$G j$ - mass of the ion exchanger in the column, $g$,

Zuw - exchange capacity of the moist ion exchanger, determined in the flow conditions, $\mathrm{mg} / \mathrm{g}$.

Considering the percentage content of moisture, the useful exchange capacity of the ion exchanger in a dry state was calculated by the following formula (5):

$$
Z u s=\frac{100 \cdot Z u w}{100-p}
$$

where: Zus - exchange capacity determined under dynamic conditions in the dry state, $\mathrm{mg} / \mathrm{g}$,

$p$ - moisture content, $\%$.

\section{RESULTS}

The ion exchange proceeded very quickly. In the case of the detergent, it decreased by $95.55 \%$ after 30 minutes of contact with the ion exchanger. After 30 minutes of contact, the phenol was reduced by $97.50 \%$. A longer contact time did not yield better results in the case of the analysed kinds of pollution (Table 3). The assumed optimal time of contact between the ion exchanger and purified solutions was $30 \mathrm{~min}$.

An increase of the ion exchanger dose up to $4.0 \mathrm{~g} / \mathrm{dm}^{3}$ resulted in an improvement of the detergent removal effectiveness to $95.55 \%$. A larger amount of the ion exchanger increased the effectiveness of the ion exchange process only by $0.05 \%$ (Table 4 ).

In the case of phenol, the ion exchanger sample that yielded satisfactory result of $97.50 \%$ reduction, amounted to $3.0 \mathrm{~g} / \mathrm{dm}^{3}$. Similarly to the detergent removal process, a larger amount of the ion exchanger caused only a slight effectiveness increase of the ion exchange process (Table 4).

In order to calculate the exchange capacity of the resin under non-flow conditions, a dose of $4.0 \mathrm{~g} / \mathrm{dm}^{3}$ was used in the case of the detergent, and a dose of $3.0 \mathrm{~g} / \mathrm{dm}^{3}$ in the case of the phenol (Table 5). The moistness of the regenerated and rinsed ion exchanger used for tests under static conditions was $64 \%$.

On the basis of tests conducted under flow (dynamic) conditions, the puncture curve of the

Table 3. Effect of contact time the ion exchange

\begin{tabular}{|c|c|c|c|c|}
\hline Contact time, min & $\begin{array}{c}\text { Concentration of } \\
\text { surfactant, } \mathrm{mg} / \mathrm{dm}^{3}\end{array}$ & $\begin{array}{c}\text { Decreasse of } \\
\text { surfactant, } \%\end{array}$ & $\begin{array}{c}\text { Concentration of } \\
\text { phenol, } \mathrm{mg} / \mathrm{dm}^{3}\end{array}$ & $\begin{array}{c}\text { Decreasse of phenol, } \\
\%\end{array}$ \\
\hline 10 & 0.96 & 95.20 & 0.87 & 95.65 \\
\hline 20 & 0.91 & 95.45 & 0.63 & 96.85 \\
\hline 30 & 0.89 & 95.55 & 0.50 & 97.50 \\
\hline 60 & 0.89 & 95.55 & 0.50 & 97.50 \\
\hline 80 & 0.90 & 95.50 & 0.50 & 97.50 \\
\hline 100 & 0.90 & 95.50 & 0.49 & 97.55 \\
\hline 120 & 0.89 & 95.55 & 0.50 & 97.50 \\
\hline 180 & 0.90 & 95.50 & 0.49 & 97.55 \\
\hline
\end{tabular}


Table 4. Influence of ionite doses on the removal of surfactant and phenol

\begin{tabular}{|c|c|c|c|c|}
\hline Ionite doses, $\mathrm{g} / \mathrm{dm}^{3}$ & $\begin{array}{c}\text { Concentration of } \\
\text { surfactant, } \mathrm{mg} / \mathrm{dm}^{3}\end{array}$ & $\begin{array}{c}\text { Decreasse of } \\
\text { surfactant, } \%\end{array}$ & $\begin{array}{c}\text { Concentration of } \\
\text { phenol, } \mathrm{mg} / \mathrm{dm}^{3}\end{array}$ & $\begin{array}{c}\text { Decreasse of phenol, } \\
\%\end{array}$ \\
\hline 0.5 & 1.52 & 92.40 & 0.94 & 95.30 \\
\hline 1.0 & 1.50 & 92.50 & 0.82 & 95.90 \\
\hline 2.0 & 1.12 & 94.40 & 0.68 & 96.6 \\
\hline 3.0 & 0.90 & 95.50 & 0.50 & 97.50 \\
\hline 4.0 & 0.89 & 95.55 & 0.50 & 97.50 \\
\hline 5.0 & 0.88 & 95.60 & 0.50 & 97.50 \\
\hline 6.0 & 0.89 & 95.55 & 0.49 & 97.55 \\
\hline 7.0 & 0.88 & 95.60 & 0.49 & 97.55 \\
\hline
\end{tabular}

Table 5. Ion exchange capacity determined under static conditions

\begin{tabular}{|c|c|c|}
\hline \multirow{2}{*}{ Type of pollution } & \multicolumn{2}{|c|}{ Ion exchange capacity, mg/g } \\
\cline { 2 - 3 } & lonite moisture & lonite dry \\
\hline Surfactant & 4,78 & 13,28 \\
\hline Phenol & 6,50 & 18,05 \\
\hline
\end{tabular}

ion exchange process were constructed for the detergent and the phenol (Figure 1 and Figure 2). The drawn graphs were used to determine the useful exchange capacity of the used ion exchanger (Table 6).

The anion-exchanger puncture point for the detergent was determined at the level of $0.1 \mathrm{mg} / \mathrm{dm}^{3}$, and for the phenol it amounted to $0.00 \mathrm{mg} / \mathrm{dm}^{3}$.

Moistness of the ion exchanger samples placed in the filtration columns amounted to $65 \%$.
The ion-exchange capacity of anion exchanger under the flow conditions was higher than the ion-exchange capacity determined under the nonflow conditions. The differences in ion exchange capacity values are related to the method of determining the ion exchange balance. In the ion exchange process carried out under non-flow conditions, the equilibrium is determined once. The exchange process carried out under flow conditions due to the batching of the model solution allows to establish new equilibrium states. This results in a better use of the ion exchange capacity. The useful exchange capacity determined for detergent during the second and the third filtration cycles were smaller than the ones received in the 1st cycle of the ion exchange process by $10 \%$. In the case of phenol, the ion-exchange capacity was smaller than in the first filtration cycle by $14.29 \%$ in the second cycle, and by $17.86 \%$ in the third cycle.

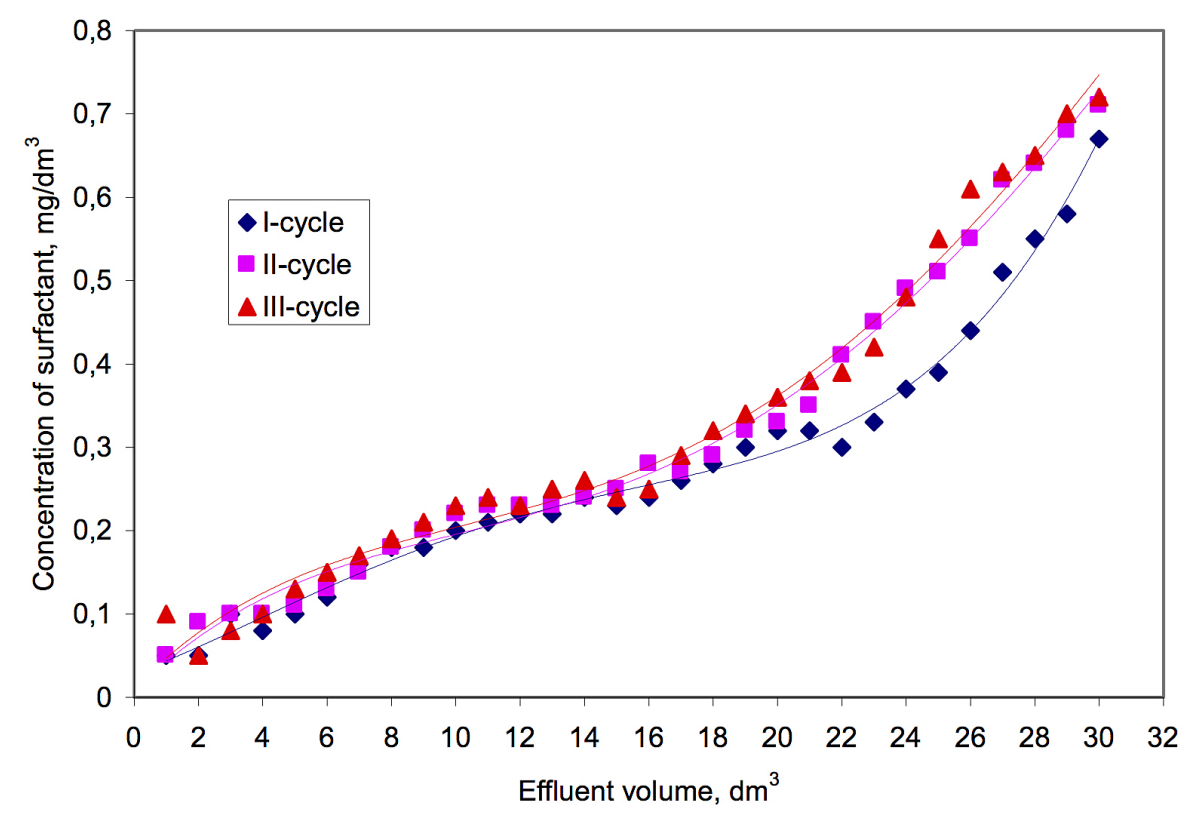

Figure 1. Ion exchange breakthrough curves (isoplanes) - (initial surfactant concentration of $20.00 \mathrm{mg} / \mathrm{dm}^{3}$, filtration rate of $10 \mathrm{~m} / \mathrm{h}$ ) 


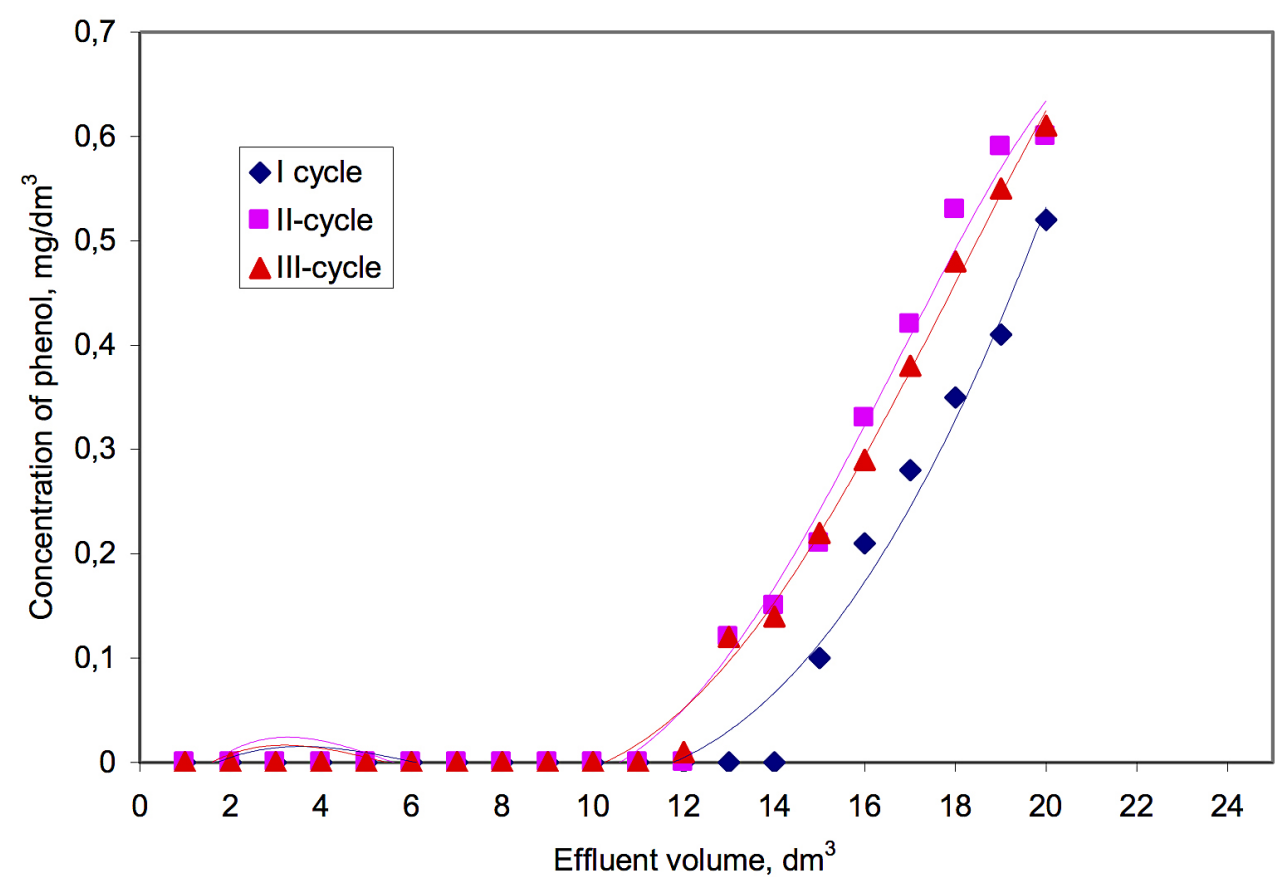

Figure 2. Ion exchange breakthrough curves (isoplanes) - (initial phenol concentration of $20.00 \mathrm{mg} / \mathrm{dm}^{3}$, filtration rate of $10 \mathrm{~m} / \mathrm{h}$ )

Table 6. Usable ion exchange capacity of AMBERLITE IRA900 Cl resin determined under flow conditions

\begin{tabular}{|c|c|c|c|c|c|c|}
\hline \multirow{2}{*}{ Type of pollution } & \multicolumn{6}{|c|}{ Usable ion exchange capacity, mg/g } \\
\cline { 2 - 7 } & \multicolumn{2}{|c|}{ I-cycle } & \multicolumn{2}{c|}{ II-cycle } & \multicolumn{2}{c|}{ III - cycle } \\
\cline { 2 - 7 } & $\begin{array}{c}\text { lonite } \\
\text { moisture }\end{array}$ & lonite dry & lonite moisture & lonite dry & $\begin{array}{c}\text { Ionite } \\
\text { moisture }\end{array}$ & lonite dry \\
\hline Surfactant & 9,90 & 26,77 & 8,91 & 24,08 & 8,91 & 24,08 \\
\hline Phenol & 14,00 & 37,84 & 12,00 & 32,43 & 11,50 & 31,08 \\
\hline
\end{tabular}

\section{CONCLUSIONS}

In the ion exchange process conducted using strongly alkaline, anion-exchange AMBERLITE IRA900 $\mathrm{Cl}$ resin yielded good results in the removal of both anionic detergent and phenol.

Anionic detergents, the largest group of the surface-active agents (ca. 80\%), decompose into surface-active anions, which is why utilising them for the anion-exchange removal was effective. The useful capacity of ion-exchange resin towards the detergent amounted to $25.60 \mathrm{mg} / \mathrm{g}$ for the first run cycle, and 22.74 for the second and the third run cycles.

Phenol is a weak acid which decomposes into a phenolic ion and a proton. The phenolic anion was removed through the ion exchange with anion-exchange resin used in the tests. The useful exchange capacity of the tested ion exchanger towards phenol amounted to $37.14 \mathrm{mg} / \mathrm{g}$ in the first run cycle, $31.42 \mathrm{mg} / \mathrm{g}$ in the second run cycle, and the least, that is, $28.57 \mathrm{mg} / \mathrm{g}$, in the third run cycle.

The useful ion-exchange capacity of the anionexchanger was larger in the case of phenol than in the case of the detergent. The detergent, due to its larger particles, entered the channels of the ion exchanger at a slower rate, and even partially obstructed the access to the place of ion exchange.

Besides the ion exchange process of the macroporous AMBERLITE IRA900 resin, an adsorption process took place as well, as proven by the useful ion-exchange capacities achieved after second and third regeneration of the ion exchanger (after second and third cycle of the ion exchanger filter). When designing an ion exchange bed, one should use exchange the capacity values received in the further work cycles of the ion exchanger, since part of the pollution filtered during the first run cycle is not removed during the regeneration process. 


\section{REFERENCES}

1. Abburi, K. 2003. Adsorption of phenol and p-chlorophenol from their single and bisolute aqueous solutions on Amberlite XAD - 16 resin. Journal of Hazardous Materials, 105, 143-156.

2. Basar, C.A., Karagunduz, A., Cakici, A., Keskinler, B. 2004. Removal of surfactants by powdered activated carbon and microfiltration. Wat. Res., 38, 2117-2124.

3. Cserhati, T., Forgacs, E., Oros, G. 2002. Biological activity and environmental impact of anionic surfactants. Environmet International, 28, 337-348.

4. Dudzik, M., Werle, S. 2015. Phenol sorption from water solution onto conventional and unconventional sorbents . Inżynieria i Ochrona Środowiska, 18(1) 67-81.

5. Guidelines for Drinking - water Quality 2017. World Health Organization, Genewa.

6. Kabsch-Korbutowicz, M. 2013 Application of Ion Exchange to Natural Organic Matter Removal from Water. Ochrona Srodowiska, Vol. 35, No. 1, 11-18.

7. Kaleta, J. 2006. Removal of phenol aqueous solution by adsorption. Canadian Journal of Civil Engineering, 33, 546-551.

8. Kaleta, J. 2008. Removal of surfactant substances from aqueous solution by adsorption. VIII Międzynarodowa Konferencja Naukowo-Techniczna "Zaopatrzenie w wodę, jakość i ochrona wód", Gniezno, 505-514.

9. Kaleta, J., Papciak, D., Puszkarewicz, A. 2013. Assessment of Usability of Bentonite Clays for Removing Phenol from Water Solutions, Annual Set the Environment Protection, 15, 2352-2368.

10. Kapica, J., Kaleńczuk, R.J., Morawski, A.W. 2002. Studies of influence specific surface area on adsorption of phenol from water by activated carbon CWZ. Mat. Konf. „Węgiel aktywny w ochronie środowiska" Wyd. Pol. Częstochowskiej, Częstochowa, 178-187.
11. Kida, M., Koszelnik, P. 2015. Environmental fate of selected micropollutants. Journal of Civil Engineering, Environment and Architecture, Rzeszów, 62(1) 279-298.

12. Kowalska, I. 2008. Separation of Surface Active Agents from Water Solutions Using Polymer Ultrafiltration Membranes. Annual Set the Environment Protection, 10, 593-604.

13. Kowalska, I. 2009. Anionic Surfactant Removal by Ion Exchange. Ochrona Środowiska 2009, Vol. 31, No. 1, pp. 25-29.

14. Lorenc-Grabowska, E., Gryglewicz, G. 2002. Adsorption of chloro- and nitrophenols from aqueous solutions on spherical activated carbons. Mat. Konf. „Węgiel aktywny w ochronie środowiska” Wyd. Pol. Częstochowskiej, Częstochowa, 195-205.

15. Mołczan, M., Biłyk, A. 2006. Use on Anion-Exchange MIEX Resin in the Treatment of Natural Water with High Colored Matter Contend. Ochrona Środowiska vol.28, no 2, 23-26.

16. Nayak, P.S., Singh, B.K. 2007. Removal of phenol from aqueous solutions by sorption on low cost clay. Desalination 207, 71-79.

17. Oghenejoboh, K.M, Otuagoma, S.O., Ohimor, E.O. 2016. Application of cassava peels activated carbon in the treatment of oil refinery wastewater - a comparative analysis. Journal of Ecological Engineering, 17, 52-58.

18. Piekutin, J. 2011. Water pollution with oil products. Annual Set the Environment Protection, 13, 1903-1914.

19. Puszkarewicz, A., Kaleta, J., Papciak, D. 2015. Removal of phenol in adsorption proces. Journal of Civil Engineering, Environment and Architecture, 62(3), 35-362.

20. Sarkowicz M., Das, M. 2001. Design and performance of fixed bed adsorption from treatment of malachite green as single solute as well as in bisolute composition. Annual Set the Environment Protection, 3, 129-237. 